\title{
K. Hakkarainen, T. Palonen, S. Paavola, \& E. Lehtinen, Communities of networked expertise: professional and educational perspectives
}

Elsevier, Amsterdam, 2004, 262 pp

\section{Richard E. West}

Published online: 15 August 2007

(C) Association for Educational Communications and Technology 2007

\section{Erratum to: Education Tech Research Dev \\ DOI 10.1007/s11423-007-9042-9}

In the online and print version of this article, a second author appeared who did not contribute to the article. Charles R. Graham's name should have been removed. 